\title{
HOOKERIA ACUTIFOLIA (HOOKERIACEAE, BRYOPHYTA), A GENUS AND SPECIES NEW FOR THAILAND
}

\author{
Wanwisa Juengprayoon, Manoop Poopath \& Sahut Chantanaorrapint ${ }^{1}$
}

\begin{abstract}
Hookeria acutifolia Hook. \& Grev. is reported here as a new genus and species record for Thailand. A description, line drawing and photographs are provided, and its lectotype is designated here.
\end{abstract}

Key words: Asia, bryophyte, distribution, Hookeria, Hookeriaceae, moss, Thailand

Wanwisa Juengprayoon \& Sahut Chantanaorrapint, PSU-Herbarium, Department of Biology, Faculty of Science, Prince of Songkla University, Hat Yai, Songkhla, 90112, Thailand; e-mail: chantanaorrapint@gmail.com

Manoop Poopath, Forest Herbarium, Department of National Parks, Wildlife and Plant Conservation, Chatuchak, Bangkok 10900, Thailand

\section{INTRODUCTION}

Thailand is well known as a hotspot of bryophyte diversity (e.g., He et al. 2012; Chantanaorrapint \& Sridith 2014; Inuthai et al. 2014, 2015; Chantanaorrapint 2015; Promma \& Chantanaorrapint 2015). The first report of mosses in Thailand was made by Brotherus (1901), who recorded 44 moss species from Koh Chang (Island), including 19 new species. Many contributions of Thai mosses have followed. The most recent Thai moss checklist (He 1998) included 620 species and 31 subspecific taxa, and some interesting mosses have been added since then (e.g., Printarakul et al. 2012, 2013, 2014; Sukkharak et al. 2014; Hassama \& Chantanaorrapint 2015; Sukkharak \& He 2015).

The genus Hookeria was first established by J. E. Smith in 1808, based on H. lucens (Hedw.) J. E. Sm. (Smith 1808; Hooker \& Greville 1825). This genus is a member of the family Hookeriaceae and contains ten species worldwide, distributed mainly in tropical and temperate regions (Lin \& Tan 1995; Frey \& Stech 2009). The genus is characterized by (1) yellowish green plant color, (2) the presence of a central stand, (3) the leaf being complanate without a costa, (4) leaf cells large, forming

\footnotetext{
1 Corresponding author
}

a net-like areolation, and (5) the mitriform calyptra (Hooker \& Greville 1825; Tan \& Robinson 1990).

While several Hookeria taxa have been published for Asia (e.g., Tan \& Robinson 1990; Lin \& Tan 1995; Bang-Juan \& Tan 2002), the genus has not been reported from Thailand (He 1998), probably due to the rareness of bryological surveys in this country (Sukkharak \& Chantanaorrapint 2014). During fieldwork devoted to the 'Bryophyte Flora of Thailand' project, specimens were recently collected in the Phu Luang wildlife sanctuary (Loei Province, NE Thailand) and Khao Luang National Park (Nakorn Si Thammarat Province, S Thailand). Based on literature and herbarium comparisons, the collections were identified as Hookeria acutifolia Hook. \& Grev., which is a new record for Thailand. The following description and illustration are based on the recent specimens from Thailand.

\section{TAXONOMIC TREATMENT}

Hookeria acutifolia Hook. \& Grev. Figs 1 \& 2 Edinburgh J. Sci. 2: 225. 1825.

TyPE: NEPAUL (= NEPAL). Wallich 7631 (HOLOTYPE: K001127560 missing). LECTOTYPE (here designated): Hook. \& Grev., Edinburgh J. Sci. 2: pl 5 (upper left). 1825. 

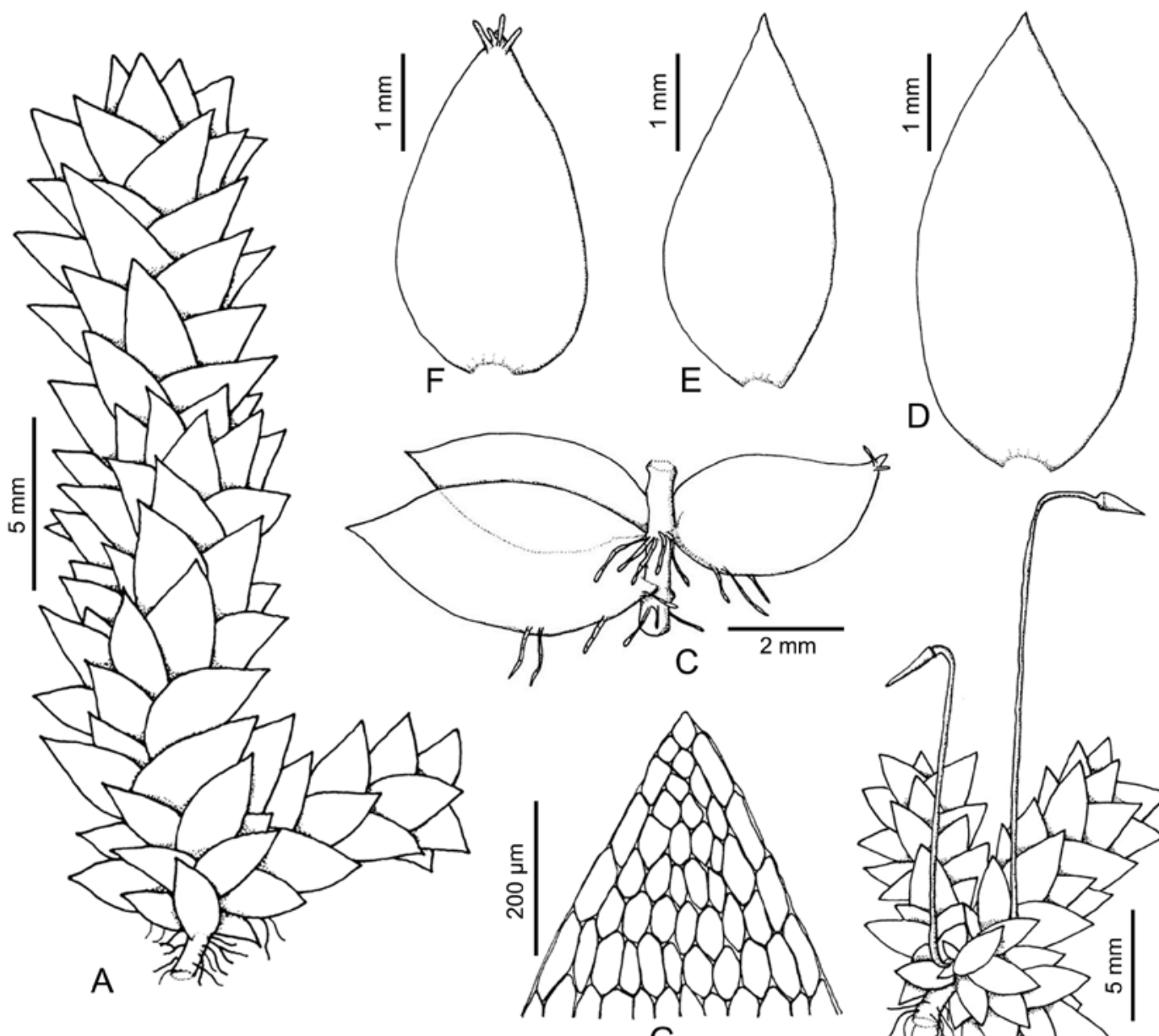

G

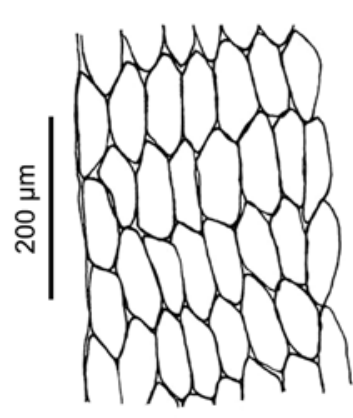

$\mathrm{H}$
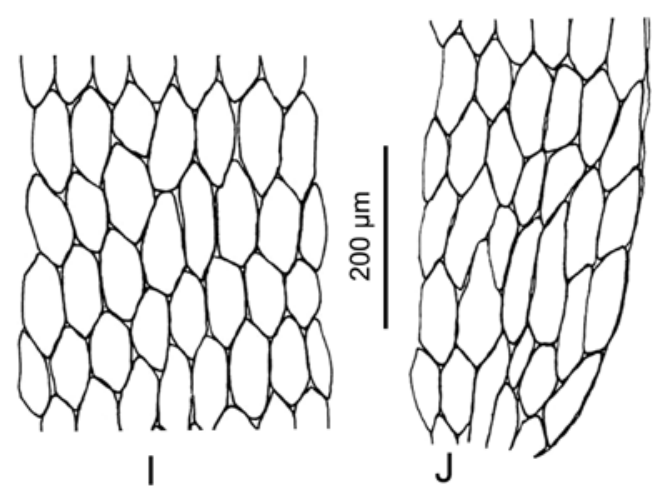
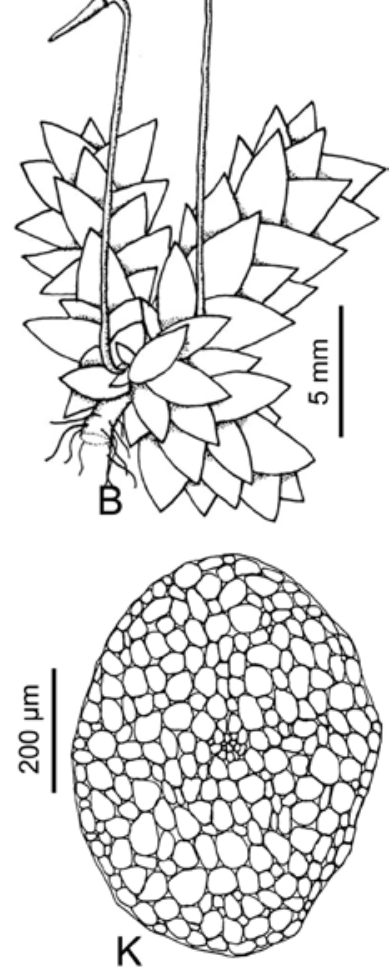

Fig. 1. Hookeria acutifolia Hook. \& Grev. A - sterile gametophyte, B - gametophyte with sporophytes, C - part of plant, D \& E - normal leaf, F - leaf with gemmae, G - cells at leaf apex, H - cells at leaf margin, I - cells at median part of leaf, $\mathrm{J}$ - cells at leaf base, $\mathrm{K}$ - cross section of stem. Drawn by W. Juengprayoon from M. Poopath 1221 (BKF). 

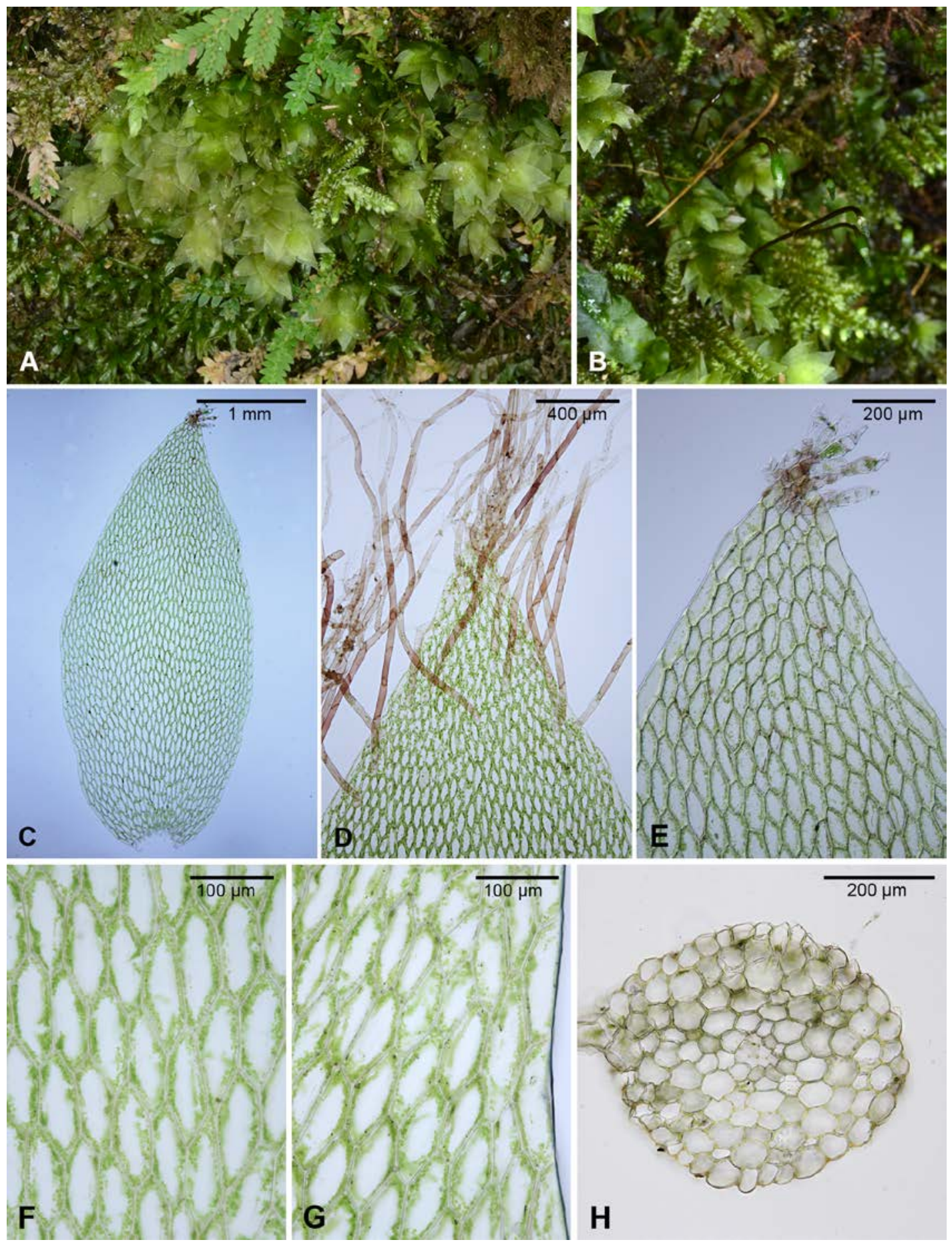

Fig. 2. Hookeria acutifolia Hook. \& Grev. A - habitat, B - gametophyte with young sporophytes, C - leaf, D - rhizoids on leaf, $\mathrm{E}$ - gemmae on leaf tip, F \& G - leaf cells, H - cross section of stem. Photo W. Juengprayoon from M. Poopath 1221 (BKF). 
Plants yellowish green, medium to large in size, $1.8-3.5 \mathrm{~cm}$ long, $1.5-2.0 \mathrm{~cm}$ wide with leaves, simple or sparingly branched, creeping and tightly adherent to substrate. Rhizoids colorless to reddish, dense along ventral surface of stem except apex. Stems green to yellowish green, in cross section with slightly differentiated central strand, 16-20 cells across, 1-2 layers of cortical cells, thin-walled; medullary cells as large as cortical ones. Leaves heteromorphic, complanate, widely spreading, somewhat curved when dry, ovate to narrowly ovate, $2.0-5.2 \mathrm{~mm}$ long, $0.4-1.5 \mathrm{~mm}$ wide, widest at base, apices broadly acute, margins entire, border not differentiated, ecostate; leaf cells large, thin-walled, apical cells short-hexagonal to rhomboidal, 40-60 $\mu \mathrm{m}$ long and $12-15 \mu \mathrm{m}$ wide, marginal and median cells short-hexagonal to irregularly pentagonal, 45-72 $\mu \mathrm{m}$ long and 18-24 $\mu \mathrm{m}$ wide, basal cells oblong-hexagonal to irregularly pentagonal, 60-90 $\mu \mathrm{m}$ long and 20-29 $\mu \mathrm{m}$ wide. Monoicous. Perigonial leaves not seen. Perichaetial leaves, narrowly ovate to lanceolate, $0.3-0.6 \mathrm{~mm}$ long, $0.1-0.3 \mathrm{~mm}$ wide, acute, entire. Seta slender, 20-28 mm long, reddish brown to yellowish brown, smooth. Capsule ovoidoblong, horizontal to pendulous, 1.0-1.8 mm long, somewhat symmetrical; operculum long-rostrate; outer peristome teeth lanceolate, striate below and papillose above; inner peristome as long as outer peristome, with high basal membrane. Calyptra mitriform. Asexual reproduction by gemmae on leaf tip.

TYPIFICATION. Hookeria acutifolia was originally described by Hooker and Greville (1825), based on Wallich's collection from Nepal. According to the Wallich Catalogue, the holotype should be Wallich 7631 located in K (K001127560). However, the bryophyte collections in $\mathrm{K}$ were transferred to BM many years ago. Unfortunately this specimen has gone missing and no duplicate of this particular specimen could be located in other herbaria. It became necessary to designate a lectotype. The illustration in the original protologue is designated here as the lectotype of $H$. acutifolia.

TAXONOMIC NOTES. The main diagnostic characters of Hookeria acutifolia are these: yellow- ish green plant, having complanately foliated branches, somewhat heteromorphic leaves mostly without a leaf border and costa, and the presence of gemmiferous leaves. Hookeria acutifolia somewhat resembles $H$. lucens in general appearance. Hookeria acutifolia, however, is distinguished from $H$. lucens by its acute leaves and the presence of filamentous rhizoids at the leaf apices.

Distribution. Widespread in Asia (China, India, Indonesia, Nepal, Philippines), Europe (Turkey), Africa, eastern North America, Central America, northern parts of South America, and also the Pacific Ocean (Hawaii) (Lin \& Tan 1995; Uyar \& Ören 2013). New for Thailand.

HaBitat AND ECOLOGY. In Thailand the specimens were found growing among other bryophytes (Fig. 2A) such as Diphyscium longifolium Griff., Hypnum sp. and Thuidium sp., on wet, shaded rocks along a stream in montane forest at $c a 1300 \mathrm{~m}$.

SPECIMENS EXAMINED: THAILAND. LOEI PROVINCE, Phu Ruea district, Phu Luang wildlife sanctuary, Rong Son Nature Trail, on wet rock along stream, $1363 \mathrm{~m}$, $17^{\circ} 17^{\prime} 51.7^{\prime \prime} \mathrm{N}, 101^{\circ} 31^{\prime} 21.17^{\prime \prime} \mathrm{E}, 7$ Sept. 2015, M. Poopath 1203, 1221 (BKF, PSU). NAKHORN Si ThAMMARAT PROVINCE, Khao Luang National Park, Khao Luang Mt., on rock, $1326 \mathrm{~m}, 08^{\circ} 32^{\prime} 51.01^{\prime \prime} \mathrm{N}, 099^{\circ} 44^{\prime} 15.44^{\prime \prime} \mathrm{E}$, 26 June 2015, W. Juengprayoon 431, 432 (PSU).

The continuous discovery of new species and new records of bryophytes from Thailand (e.g., He et al. 2012; Kornochalert et al. 2012; Chantanaorrapint 2014, 2015; Inuthai et al. 2014, 2015; Chantanaorrapint \& Sridith 2014; Promma \& Chantanaorrapint 2015; Sukkharak \& He 2015) suggests that many bryophyte taxa await discovery in this country. More detailed investigations of the bryophytes of Thailand, particularly in the northern and southern parts of the country, should prove rewarding and are likely to lead to the discovery of interesting new taxa.

ACKNOWLEDGEMENTs. We thank the curators and staff of BKF for kindly allowing us to study specimens, and Professor Ryszard Ochyra and the anonymous reviewers for helpful remarks and suggestions on the manuscript. This work was supported by the Prince of Songkla University Research Fund within the Plant 
Genetic Conservation Project under the Royal initiative of Her Royal Highness Princess Maha Chakri Sirindhorn.

\section{REFERENCES}

BAng-JUAN L. \& TAN B. C. 2002. Hookeriaceae. In: W. PengCHENG \& M. R. Crosby \& S. He (eds), Moss flora of China 6: 3-34. Science Press and Missouri Botanical Garden Press. Beijing, NewYork \& St. Louis.

Brotherus V. F. 1901. Bryales. In: J. SchmidT, Flora of Koh Chang III. Bot. Tidsskr. 24: 115-125.

Chantanaorrapint S. 2014. Notothylas irregularis (Notothyladaceae, Anthocerotophyta), a new species of hornwort from northern Thailand. Acta Bot. Hung. 56(3-4): 267-272.

Chantanaorrapint S. 2015. Taxonomic studies on Thai Anthocerotophyta II. The genus Notothylas (Notothyladaceae). Cryptog. Bryol. 35: 251-266.

Chantanaorrapint S. \& Sridith K. 2014. The genus Plagiochasma (Aytoniaceae, Marchantiopsida) in Thailand. Cryptog. Bryol. 35: 127-132.

Frey W. \& Stech M. 2009. Marchantiophyta, Bryophyta, Anthocerotophyta. In: W. Frey (ed.), Syllabus of plant families - A. Engler's Syllabus der Pflanzenfamilien, $13^{\text {th }}$ ed., Part 3, Bryophytes and seedless vascular plants, pp. 9-263. Schweizerbart, Stuttgart.

Hassama B. \& Chantanaorrapint S. 2015. Species richness of bryophytes at Chao $\mathrm{Pa}$ waterfall, Trang province. Thai J. Bot. 7: 27-45.

HE S. 1998. The floristic composition and phytogeographical connections of Thai mosses. J. Hattori Bot. Lab. 84: 121-134.

He Q., Zhu R.-L., Chantanaorrapint S., KornoChalert S. \& Printarakul N. 2012. Drepanolejeunea laciniata (Lejeuneaceae), a new species from northern Thailand. Cryptog. Bryol. 33: 291-298.

Hooker W. J. \& Greville R. K. 1825. On the genus Hookeria of Smith, of the order Musci. Edinburgh J. Sci. 2: 221-236.

InUthai J., Zhu R.-L. \& Chantanaorrapint S. 2014. Drepanolejeunea actinogyna (Lejeuneaceae), a new species from southern Thailand. Bryologist 117: 165-169.
InUthai J., ZhU R.-L. \& Chantanaorrapint S. 2015. Taxonomic notes on Drepanolejeunea pleiodictya (Marchantiophyta, Lejeuneaceae), a little-known Asiatic species. Polish Bot. J. 60: 13-17.

Kornochalert S., Santanachote K. \& Wang J. 2012. Lejeuneaceae subfamily Ptychanthoideae (Marchantiophyta) in Thailand. Cryptog. Bryol. 33: 39-63.

LiN P.-J. \& TAN B. C. 1995. Contribution to the Bryoflora of China (12): A taxonomic revision of Chinese Hookeriaceae (Musci). Harvard Pap. Bot. 7: 25-68.

Printarakul N., Benito B.C., Santanachote K. \& WongKUNA K. 2012. Nine new records of mosses from Doi Suthep-Pui National Park and a new variety of Fissidens from Thailand. Cryptog. Bryol. 33: 23-31.

Printarakul N., Benito B. C., Santanachote K. \& Akiyama H. 2013. New and noteworthy records of mosses from Doi (Mt.) Inthanon, Chiang Mai, Chom Tong District, Northern Thailand. Polish Bot. J. 58: 245-257.

Printarakul N., Tan B. C., Wongkuna-Thananoppakun K. \& Santanachote K. 2014. The Indian connection of the Thailand moss flora, with one new species, Fissidens elizbrowniae. Telopea 17: 195-215.

Promma C. \& Chantanaorrapint S. 2015. The epiphyllous Radula (Radulaceae, Marchantiophyta) in Thailand, with the description of Radula grandilobula sp. nov. Cryptog. Bryol. 35: 217-234.

Sмith J. E. 1808. Characters of Hookeria, a new genus of mosses, with descriptions of ten species. Trans. Linn. Soc. London 9: 275-282.

SukkharaK P. \& Chantanaorrapint S. 2014. Bryophyte studies in Thailand: past, present, and future. Crytog. Bryol. 35: 5-17.

SukkharaK P. \& He S. 2015. Schwetschkeopsis fabronia (Schwägr.) Broth. (Bryophyta: Fabroniaceae): a species new to Thailand. Telopea 18: 371-374.

Sukkharak P., Kitlap P., Likananonn A. \& He S. 2014. A preliminary study of bryophytes in the Khao Soi Dao wildlife sanctuary, Chanthaburi Province, Thailand. Songklanakarin Journal of Science and Technology 36: 527-534.

Tan B. C. \& Robinson H. 1990. A review of Philippine Hookeriaceous taxa (Musci). Smithsonian Contr. Bot. 75: 1-41.

UYAR G. \& ÖREN M. 2013. Three remarkable new moss records for South-West Asia from northern Turkey. Turkish Journal of Botany 37: 363-368. 